\title{
EXCLUSIVE BREASTFEEDING AMONG WORKING MOTHERS IN JABODETABEK, INDONESIA
}

\author{
Retno Wulandari'), Evi Martha'), Essi Guspaneza'), Aliyah Cendanasari'), Lisna \\ Agustiyah'), Nurhotimah'), Sofia'1), Sonia Mahrudin'1) \\ 1)Masters Program in Public Health, Universitas Indonesia \\ 2)Department of Health Education and Behavior Sciences, \\ Faculty of Public Health, Universitas Indonesia
}

\begin{abstract}
Background: One of the priorities of the Sustainable Development Goals (SDGs) is to reducing infant and toddler mortality. Infant Mortality Rate (IMR) in Indonesia remains high. IMR is affected by various factors, one of which is exclusive breastfeeding (EBF). World Health Organization recommends EBF of infants for the first 6 months of life. In Indonesia, the population of working mothers is getting bigger. However, the EBF coverage in this population has not reached the national target. This study aimed to describe the EBF behavior and to examine the predisposing, enabling and reinforcing factors of EBF among working mothers in Jabodetabek, Indonesia.

Subjects and Method: This was a qualitative study using the Rapid Assessment Procedure (RAP). The sample of this study were 16 informants in the Jabodetabek area, consisting of 5 working mothers, 5 husbands, 5 coworkers, and 1 breastfeeding counselor. Variable in this study were EBF, maternal knowlede, perception, occupation, number of children, husband support, coworkers support, and supporting facilities at work. The data were collected using a semi-structured in-depth interview.

Results: The informants' knowledge of the definition, benefit, and content of breast milk were good. All informants had supportive perception of EBF. Informants with more than one child felt that EBF for the second child was easier. Both husband and co-workers provided full support for $\mathrm{EBF}$. The maternal occupational factor was of little importance in this study. The provision of EBF room varies. Some already had an EBF room with complete facilities, others had incomplete facilities, and some without EBF room.

Conclusion: Working mothers in Jabodetabek area have practice EBF with various obstacles. In order to improve EBF among working mothers, some factors must be considered, including maternal knowledge, perception, and the number of children (predisposing factor). Other important factors included husband and colleague support (reinforcing factor), and supporting facilities in the workplace (enabling factor).
\end{abstract}

Keywords: exclusive breastfeeding, knowledge, support, facilities, working mothers

\section{Correspondence:}

Retno Wulandari, Evi Martha. Masters Program in Public Health, Universitas Indonesia, Depok, West Java, Indonesia, Department of Health Education and Behavior Sciences, Faculty of Public Health, Universitas Indonesia. Email: drgretnow@gmail.com, evimartha@yahoo.com. Mobile: o87870227342, 08174883103 .

\section{BACKGROUND}

Sustainable Development Goals (SDGs) are a global plan of action agreed by world leaders, including Indonesia, to end poverty, reduce inequality and protect the environment. The SDGs contain 17 goals and 169 targets which are expected to be achieved by 2030 (SDGs, 2017). The priority target of SDGs in Indonesia is in the Third Goal Social Development Pillar which is to end preventable infant and toddler mortality, by reducing infant mortality by 12 per 1,000 
$\mathrm{KH}$ and under-five mortality per $25 \mathrm{KH}$ (Ermalena, 2017).

Infant Mortality Rate (IMR) in Indonesia in 2012 was 32 per 1,000 live births and decreased to 24 per 1,000o live births in 2017 (SDKI, 2012). The three main causes of infant death are infection, perinatal complications and diarrhea (WHO, 2008). WHO in Thet et al (2016) recommends exclusive breastfeeding as the main strategy to reduce IMR, especially in developing countries. The long duration of exclusive breastfeeding will increase sensory and cognitive development, protect infants from chronic infections and diseases, and reduce IMR caused by diarrhea and pneumonia.

Considering how much benefit is obtained from breast milk, especially in the process of growth and development of children and the amount of loss caused if the baby is not given breast milk, then every mother is expected to be able to provide enough milk for children both in quantity and quality (MOH, 2010). However, coverage of exclusive breastfeeding in Indonesia is still relatively low and still far from the national target.

Coverage of exclusive breastfeeding tends to fluctuate from year to year, which is 32\% (Riskesdas, 2007), 42\% (Riskesdas, 2013), 29.5\% (Pusdatin Ministry of Health, 2016), 35.73\% (Pusdatin Ministry of Health, 2017) while The results of Riskesdas 2018 exclusive breastfeeding in Indonesia reached $37.3 \%$. While the target in Indonesia for exclusive breastfeeding is $80 \%$. From the data it can be seen that there is a gap between the target and the achievement of exclusive breastfeeding in Indonesia.

The success of exclusive breastfeeding is influenced by several factors, such as sociodemographic, psiocosocial, pre and post natal factors, mother's knowledge and attitude, and the occupational status of the mother. According to Kurniawan (2013), working mothers face various obstacles in exclusive breastfeeding, including time allocation, quality of being together with babies, workload, stress, and the belief of mothers to give exclusive breastfeeding. Working mothers have low confidence in being able to breastfeed exclusively. According to Balogun et al (2015), the main obstacle to exclusive breastfeeding in developing countries is the employment status of mothers. In Myanmar, it is known that the demands of working mothers who must immediately go back to work outside the home become one of the obstacles in giving exclusive breastfeeding (Thet et al., 2016). In China, some mothers are also forced to stop exclusive breastfeeding because they have to go back to work (Chen et al., 2019).

The participation of the Indonesian women's workforce in the formal and informal sectors tends to increase in line with the current modernization. Data from the Indonesian Central Statistics Agency shows an increasing trend in the percentage of women working from year to year. The level of female labor force participation in 2017 is $55.04 \%$ while in 2018 it has increased to $55.44 \%$ (BPS, 2018). Women working in the formal pathway amounted to $37.78 \%$ in 2015 , increasing to $38.16 \%$ in $2016,38.63 \%$ in 2017 , but slightly decreased to $38.20 \%$ in 2018 (BPS, 2018).

One factor related to the success of exclusive breastfeeding for working mothers is the work environment, in this case the supporting facilities for exclusive breastfeeding in the workplace. Through the Minister of Health Regulation No.15 of 2013 concerning Procedures for Providing special facilities for breastfeeding and/ or expressing mother's milk, it is expected that working mothers can continue to give milk exclusively to their babies for up to 6 months. 
Seeing the importance of exclusive breastfeeding, the phenomenon of increasing numbers of women workers and the complexity of the challenges of exclusive breastfeeding to working women, the authors are interested in conducting research to find out how the portrait of exclusive breastfeeding and the behavior of exclusive breastfeeding to working mothers in Jabodetabek area and to identify factors what predispossing, enabling and reinforcing factors influence it.

\section{SUBJECTS AND METHOD}

\section{Study Design}

The design used was a qualitative method with Rapid Assessment Procedure (RAP) approach. It was conducted in the Greater Jakarta area (Jabodetabek) in April 2019. The selection of informants was carried out by means of purposive sampling based on suitability, adequacy and saturation.

\section{Study Variables}

The variables in this study were exclusive breastfeeding among working mothers in the Greater Jakarta area (Jabodetabek), mother's knowledge, mother's perceptions, work, number of children, husband's support, support from colleagues, and facilities that support the workplace.

\section{Criteria for Inclusion and Exclu- sion}

The inclusion criteria in this study included women aged 20-40 years who had completed exclusive breastfeeding, had the status of a worker when giving exclusive breast feeding, the age of children who were successfully given exclusive breastfeeding a maximum of 18 months when the study was carried out, physically and mentally healthy, and willing be informants. The data source in this study is primary data obtained through in-depth interviews (indepth interview) semi-structured to 16 informants in the Greater Jakarta area, consisting of 5 working mothers, 5 husbands, 5 coworkers and 1 ASI counselor as an informant key.

The study instrument was the informant himself who was equipped with interview guides, field notes sheets and recording devices. The method of analysis in this study is theme analysis, while the steps in data processing include data reduction, data presentation, and drawing conclusions.

\section{RESULTS}

Informants in this study were divided into 3 groups, namely the first group were mothers who passed exclusive breastfeeding, the second group were mothers who passed exclusive breastfeeding, and the third group were coworkers who passed exclusive breastfeeding.

Each group consists of 5 people. Informants in the first group are mostly Civil Servants with the youngest age of 29 years and the oldest 33 years. They are active workers with solid work routines, both those who work in service, office and private sector.

The informants in the second group are mostly private employees with the youngest age 34 years and the oldest 37 years, while the informants in the third group the youngest age are 26 years and the oldest 36 years. The key informant in this study was a nutritionist as well as a 40year-old ASI counselor who was a civil servant.

Talking about informant breastfeeding behavior, we can know when the informants are at home, in general they breastfeed their babies directly every 2 hours or according to the wishes of the baby, while when they are in the office, the baby will consume dairy milk (ASIP). The informant stated that the milk ASI was prepared since they were on leave, which is 2 months before returning to work, and they routinely 
pump ASI every 2 hours. Dairy milk is stored in the freezer using ASIP bags or glass bottles, then the day before it is given to the baby ASIP is lowered to the chiller with the principle of ASIP first entering the freezer will be issued / drunk to the baby first. The informant said that while in the office, they pumped breast milk with a frequency of 2-3 times, whereas when at home, they pumped at least 2 times, ie when returning from work and at dawn.

"Sehari di rumah kurang lebih setiap 2 jam nyusuin itu sekitar 3-5 kali yaa kalau di kantor mompa ya paling 2 sampai 3 kali. Saya kan setengah 8 ya dari rumah trus mompa itu ee biasanya jam 10 jam 12 sama sebelum pulang jam setengah $2 a n$. Tapi rata-rata 2 kali sih" (Informant 2)

"In a day at home, usually every 2 hours, I breastfeed around 3-5 times. At the office, I pump at most 2 to 3 times. I am half past 8 leaving home, then I pump it usually at 10 o'clock at 12 o'clock and before returning home at half past two. But on average I pump twice"(Informant 2)

"Persiapannya dari 2 bulan mau kerja mulai pumping waktu ituooh saya pakai kantong ASIP biar praktis, jadi kalau besoknya mau dikasihin malemnya saya turunin tuh dari freezer ke kulkas yang di bawah" (Informant 2)

Preparation from 2 months want to work start pumping, at that time I used an ASIP bag so that it was practical, so if I want to give it the next day, I will bring it down from the freezer to the refrigerator below" (Informant 2)

"Ya persiapannya harus ada perlengkapan untuk stok ASI dan rutin memerah ASI tiap 2 jam sekalisaya pakai botol kaca biar gampang ee tandanya tanggal aja keluarin yang tanggalnya lebih lama"
(Informant 3)

"Yes, the preparation must have equipment for ASI stock and must routinely express milk every 2 hours. I use a glass bottle so it's easy, just sign the date, just remove the date that is longer"(informant 3)

“Cuman kalau mompa ASI, ya aku selalu ngasih target. Jadi di kantor 3 kali sesi, nanti kan pulang kerja masih dapet 1 sesi lagi, lalu subuh dapet 1 sesi lagi” (Informant 4)

"Only when pumping breast milk, yes I always give a target. So, in my office I have 3 sessions, then I will still get 1 session back from work, then after dawn I will get 1 session again"(informant 4).

They provide breast milk directly, namely the baby breastfeeding, or indirectly, namely breastfeeding with the help of tools. Most of the informants use pacifiers as aids with the consideration that the child caregivers are less able to give milk through other tools that are recommended such as a spoon or shot glass.

"Jadi kalau (cara pemberian) direct itu kalau pas ada dirumah, tapi kalau pas selama di kantor, eepompa, perah" (Informant 4)

"So if the method is given directly when I am at home, but if while in the office, I pump" (Informant 4)

"pake media apa namanya dot, sebenernya gak disarankan yah sama konselorkonselor tapi apa namanya karena eee pertimbangannya kasian yah klo anak ditinggal dirumah kasian sama yang jagain, yang jagain itu kebetulan aku dapetnya gak telaten untuk nyendokin atau sloky itu gak telaten jadi ya udah pake dot waktu itu dan anaknya untungnya bisa pakai dot" (Informant 5) 
"Using the media, namely pacifiers, actually it is not recommended by counselors, but the consideration is that I feel sorry for my child who are left at home and feel sorry for the babysitter, the babysitter is inadvertently lacking in scooping or sloky, so yes use pacifiers at that time and their children fortunately you can use pacifiers"(Informant 5)

The behavior of breastfeeding is based on a fairly good knowledge of exclusive breastfeeding. The results showed that all informants in the three groups understood very well the definition and benefits of exclusive breastfeeding and the content of breast milk. According to them, Exclusive ASI is ASI given by the mother to her child from birth for a minimum of 6 months without additional food and drink and continued for up to 2 years. Informants in all three groups argued that the benefits of breastfeeding include adding nutrition to the baby, increasing endurance of the baby, increasing the bond between mother and baby, as a natural birth control, preventing bleeding and breast cancer in the mother, as well as being more economically financial. Almost all informants in the first group knew the contents of breast milk, namely colustrum, vitamins, carbohydrates, proteins, minerals and fats.

"ASI eksklusif adalah pemberian ASI pada anak dalam jangka minimal 6 bulan maksimal 2 tahun. Diberikan sejak lahir" (Informant 3)

"Exclusive breastfeeding is breastfeeding for children in a minimum period of 6 months, a maximum of 2 years and given from birth" (Informant 3)

"Ee manfaatnya kalau untuk bayi itu ee yang pertama untuk menciptakan kekebalan juga ee dan juga dia ASI ini juga sebagai sumber nutirsi tentunya untuk bayi. Ee untuk ibu ada saya rasa ada banyak yang pertama ee meningkatkan bonding attachment dengan bayi apa sih ikatan emosi dengan bayi kemudian juga ee salah satu KB alami ya itu” (Rekan Kerja Informant 2).

"The benefit for the baby is to create immunity and breast milk as a source of nutrition for babies. And for mothers, I think there are also many benefits, the first is to increase bonding attachments with babies and also one of natural birth control" (Informant's Colleague 2).

"kolustrum itu vitamin yang paling berharga dalam itu ada immunoglobulin yak pokoknya untuk membuat imunitas tubuh bayi deh, terus yang kesini kesinya mengandung lemak, protein, mengandung segala macam bahan yang dibutuhin oleh perkembangan bayi (Informant 1)

"Colustrum is the most valuable vitamin in breast milk and there is immunoglobulin also to make the baby's immune system, continues to also contain fat, protein, and contains all kinds of ingredients needed by the baby's development (Informant 1)

The perception of the informants in the group of breastfeeding mothers is quite good, they expressed support for exclusive breastfeeding given the content of breast milk and the many benefits of breast milk. During exclusive breastfeeding, they experience various obstacles such as too large nipples, nipple pain and blisters, lumps in the breast, low milk production, and obstacles from the baby's side such as confused baby putting and tongue tie. Most of the informants stated that they had thought to stop exclusive breastfeeding, especially after children aged over 1 year due to workloads, transportation problems when working or seeing other people's children are fatter, but this was not done because of determination and strong intention. 
"Tanggapannya saya mendukung sekali karena ASI itu bagus mbak, masyaAllah kandunganya dan saya pro ASI Eksklusif gimanpun anak saya harus ASI" (Informant 1)

"My response, I am very supportive because breastfeeding is good mbak, masyaAllah the content and I am pro Exclusive ASI however my child must breastfeed" (informant 1)

"Iya waktu itu emang lagi banyak pekerjaan juga menjelang akreditasi tu ya eee pulang malem kan biasanya siang tu udah di rumah jam 3 an udah di rumah ini jam 7 malem trus karena stress juga eee apa hasil pompa juga naik turun" (Informant 2)

"Yes, at that time there were a lot of work ahead of the accreditation too, so I went home at night when usually at noon I was at home at 3 an, and at that time at $7 \mathrm{pm}$ just returned. And because of stress too, the pump results go up and down"(Informant 2)

"Pernah. Di bulan ke....setahun 2 bulan, 14 bulan. 14 bulan itu aku udah mulai hopeless buat ngasih ASI. Kepikiran pengen berhenti ee dulu itu karena lihat anakanak lain yang seumuran lebih gemuk, lebih montok dibanding anak aku" (Informant 4)

"Ever. When the age of a year 2 months, 14 months. 14 months that I have started hopeless to breastfeed. The thought of wanting to stop first was because I saw other children whose age was fatter and more plump than my child"(Informant 4)

Key informants stated that the perceptions and behavior of working mothers in the office at this time were good enough. This is related to increased awareness and level of knowledge of the mother. The current information flow can be accessed through various media.

"Saat ini, sudah banyak ibu-ibu yang bekerja itu tetep memberikan ASI eksklusif, karena ia begitu sudah banyak dukungan baik itu dari keluarga, tempat kerja ada rekan kerja yang selalu mengingatkan sudah banyak... lebih banyak lagi dibanding yang dulu-dulu" (Informant Kunci)

"Currently, there are many mothers who work and continue to provide exclusive breastfeeding, because she has so much good support from the family, the workplace there are coworkers who always remind...more than ever before" (Key Informant)

"Mungkin faktor kesadaran ya... karena ada pengetahuannya, peningkatan pengetahuan jadi kesadaran bahwa bagaimanapun ASI itu, adalah yang terbaik... seperti itu... jadi tetep memberikan ASI walaupun dia bekerja" (Informant Kunci)

"Maybe the awareness factor ... because of the knowledge, the increase in knowledge is the awareness that however ASI is, the best ... like that ... so still giving ASI even though she works" (Key Informant)

Most of the informants in this group of mothers who passed exclusive breastfeeding have two children. They stated that the experience of giving exclusive breastfeeding to each child was almost the same, but the second child was easier because it was experienced and had been exposed to a lot of information.

"Anak saya kan 2 , yang pertama asi eksklusif dan yang kedua juga sama. pengalaman saya dua-duanya kurang lebih sama. ngga ada perbedaan, nah anak kedua ini kan udah jadi lebih gampang dan informasi tentang asi eksklusif udah ba- 
nyak" (Informant 5)

"My child is 2, the first is exclusive breastfeeding and the second is the same. My experience is more or less the same. There is no difference, now this second child has become easier and information on exclusive breastfeeding has increased" (Informant 5)

According to the first group of informants, they can succeed because of their strong intention and self-drive to provide exclusive breastfeeding. In addition, the support of those closest to the family and work, namely husband and coworkers, also influences. The closest people also help in dealing with obstacles faced by mothers during breastfeeding. It turned out that her husband and coworkers also considered that their support was needed by a nursing mother. The results of interviews with husbands stated that they support mothers in giving exclusive breastfeeding by encouraging them, buying nutritious food, buying breast pumping equipment, keeping their wives pumping breast milk.

"Saya beliin peralatan buat susu perahnya mbak kayak alat pompa sama botol buat ASInyasaya ngasih makanan yang bergizi dan sehat biar ASInya bagus dan banyak, istri juga bisa sehat, Kalau istri saya nyusuin tengah malam pasti ikutan bangun mba. Kalau anak nangis pas tengah malam kadang saya gendong dulu buat bikin dia tidur lagi tapi klau masih nangis baru saya bangunin istri saya Saya sering kasih semangat ke istri saya" (Suami Informant 1)

"I bought equipment for her milk which is like a pump and a bottle for her milk. I gave her a nutritious and healthy food so that the milk is good and plenty, my wife can also be healthy. If my wife is breastfeeding at midnight, I will definitely wake up. When a child cries at midnight, sometimes I pick up first so that he sleeps again but if I still cry too, then I wake my wife. I also often encourage my wife"(Informant's Husband 1)

While the support provided by coworkers, among others, provides the opportunity to pump breast milk, replace tasks in the office, remind one another and encourage.

"Saya memberikan waktu memberikan kesempatan untuk memerah. menggantikan ee misalnya dia sedang jaga di IGD ketika saya bisa saya gantikan" (Rekan kerja Informant 2)

"I give time and give a chance to blush. I also replaced him, for example he was on duty at the emergency room if I could be replaced"(Informant's coworker 2)

"Mmmm kadang mengingatkan saja kalau biasanya jam dia pumping” (Rekan Kerja Informant 3)

"Sometimes I just remind you usually when it's pumping" (Informant's Colleague 3)

"Aku support ke temen kita yang menyusui, pasti bikin dia jadi lebih semangat. Terus kita kasih kenyamanan pas dia lagi pompa ASI. Contohnya tuh kita ngga gangguin dia pas pumping, kasih waktu dia sampe selesai” (Rekan Kerja Informant 4)

"I support our friend who is breastfeeding, surely that will encourage her. Then we also give comfort when she is pumping breast milk, for example by not disturbing her when she is pumping, and giving her time to finish" (Coworker Informant 4)

Key informants stated that the support of family and coworkers is very important to create a conducive atmosphere for working mothers who provide exclusive breastfeeding. And nowadays, there are standard rules regarding the provision of 
lactation facilities at work that make it easier for working mothers to express milk in the office.

"Sudah ada dukungan dari suami, terus alhamdulillah keluarga sangat mendukung, jadi kalo pada saat ibu menyusui suasana dirumah juga alhamdulillah mendukung sehingga pabrik ASI yang keluar itu lancar, karena kalo misalnya pikirannya terganggu atau lagi ee...stress itu pasti ASI nya yang keluar nggak banyak maka harus dijaga jangan smpai stress" (Informant Kunci)

"There is support from the husband, and thank God the family is very supportive, so if the mother is breastfeeding the atmosphere at home is also alhamdulillah support so that the ASI factory that comes out is smooth, because if for example her mind is disturbed or under stress it will definitely come out not much milk, then it must be maintained so as not to stress" (Key Informant)

“di tempat bekerja sudah ada kebijakan misalkan SK tentang 10 langkah keberhasilan menuju menyusui, bentuknya sekarang udah dibuat ruangan untuk menyusui terus adaeesarana yang mendukung, sekarang di setiap ruangan juga hampir semuanya sudah punya kulkas jadi untuk penyimpanan ASI insyaAlloh kualitasnya lebih aman dengan penyimpanan suhunya dari tempat kerja juga, kalo yang rekan kerja kadang ada yang mengingatkan...misalnya pada saat jamnya pumping ada yang ingetin ayo ee...ASInya diperah taro di kulkas jadi teman-teman ruangan ikut mendukung" (Informant Kunci)

"In the workplace there is a policy for example SK about the 10 steps to success in breastfeeding, the form has now been made room for breastfeeding and there are facili- ties that support, now in every room also almost all have a refrigerator so for ASI storage, God willing, the quality is safer with storage of temperature from the workplace too, if there are colleagues who sometimes remind, for example during pumping hours there is a reminder. The milk is milked and put in the refrigerator, so the room's friends also support” (Key Informant)

Provision of special lactation space at work looks varied. Most of the informants stated that their office had provided a special room for breastfeeding and pumping breast milk with different levels of comfort, starting with those who were less qualified to those who were awarded number 3 from the Ministry of Health. However, there was also an informant who stated that there was no specific room in his office, so he had to pump on his desk.

"Ruang ASI ada kok nyaman banget yaa ada AC pokoknya nyaman, kalau boleh sombong itu mendapat penghargaan no 3 dari kemenkes yang terbaik. yeyeye. Saya merasa leluasa mbak karena nyaman banget" (Informant 1)

"There is an ASI room and it's really comfortable because there is AC, if you can be arrogant, it has already received the No. 3 award from the Ministry of Health as the best. I feel free because it's really comfortable" (Informant 1)

"Ada tapi itu kecil banget sama gak ada lampunya gerah juga gak ada kipasnya kadang dipakai untuk taruh barang promkes jadi ya kotor gitu kan ya" (Informant 2)

"There is, but it's really small and there's no light so it's hot and there's no fan. Sometimes it is used to put promkes items so they are rather dirty"(Informant 2) 
"Belum ada ruang khusus ya, jadi di tempat meja kerja sendiri aja” (Informant 3)

"There is no specific room yet, so I am pumping at my own desk" (Informant 3)

The provision of supporting facilities for giving breast milk also varies. Some informants stated that there are already complete breastfeeding / breastfeeding support facilities at their workplaces, ranging from standard support facilities such as breastmilk pumps and special breastmilk refrigerators, to other supporting facilities such as sofas, sinks, and some MP3s. However, some informants stated that there were only standard supporting facilities in their workplaces.

"Ada AC, ada sofa, ada wastafel untuk cuci tangan, untuk bersih-bersih alat pompa ASI, ada kulkas juga untuk nympan ASI lalu ada... ee semacam mp3 begitu jadi buat lebih ke relaksasi ketika kita pas mompa ASI" (Informant 4)

"There is air conditioning, there is a sofa, there is a sink to wash hands, to clean the breastmilk pump, there is also a refrigerator to store breastmilk and then there is an mp3 so it is good for more relaxation when we are pumping breast milk" (Informant 4)

"Fasilitasnya ada kok disedikan pompa ASI, freezer khusus tempat menyimpan ASI" (Informant 1)

"There are facilities, provided for breast milk pumps, and freezers specifically for storing breast milk" (Informant 1)

\section{DISCUSSION}

This study examines four factors facilitating the success of exclusive breastfeeding, namely mother's knowledge, mother's perception, number of children and mother's occupation. The facilitating factors for the success of exclusive breastfeeding that stood out in this study were mother's knowledge, mother's perception, and the number of children.

The results showed that the knowledge of informants of nursing mothers, coworkers and husbands was quite good, they knew what understanding, benefits, and content of breast milk. According to Notoatmodjo (2007), knowledge about the benefits of breastfeeding has a strong influence on the beginning and period of breastfeeding. Knowledge is very important for the formation of one's actions. Good knowledge of informants is a major factor in the success of exclusive breastfeeding. This is consistent with the study of Purwaningsih et al (2015) that a correct mother's knowledge about exclusive breastfeeding will increase the success of exclusive breastfeeding.

Another easy factor that stands out is the perception of the working mother. The research findings reveal that the perception of all informants towards exclusive breastfeeding is very supportive. The formation of perceptions in favor of exclusive breastfeeding to working mothers is inseparable from the awareness of the benefits of exclusive breastfeeding and the value embedded in individuals. Perception is a product or the result of a psychological process experienced by someone after receiving stimuli that encourage the growth of motivation to respond to do or not do an activity. In the context of the perception of working mothers, the response to exclusive breastfeeding can be in the form of giving or not giving exclusive breastfeeding to their babies. Among personal characteristics that influence perception are personality, motivation, interests or interests, experience and expectations (Roesli, 2009).

Other findings reveal that the number of children is also an easy factor. In this study, four out of five informants had two 
children. If viewed from the literature, mothers with more than one parity or delivery will experience an increase in the amount of milk production. Soetjiningsih (1997) states that the amount of milk production in the second child $( \pm 654 \mathrm{ml} / 24$ hours) and third ( $\pm 602 \mathrm{ml} / 24$ hours) is more than the amount of breast milk in the first child ( $\pm 580 \mathrm{ml} / 24$ hours).

Another factor examined in this study is mother's occupation, but the findings regarding mother's occupation are less prominent. This is because with almost the same educational background, all informants are working mothers with similar job characteristics, namely as office bearers, both in government institutions and private companies.

In addition to facilitating factors, the success of exclusive breastfeeding by working mothers is also influenced by reinforcing and enabling factors. The reinforcing factor in this study is the support from the closest people, namely husband and coworkers. Notoatmodjo (2007) said that support is verbal or non-verbal information, suggestions, assistance, real or behavior given by people who are familiar with the subject in their social environment or in the form of attendance and things that can provide emotional benefits or influence on the recipient's behavior.

This study shows that the husband is very supportive of exclusive breastfeeding both physically and psychologically. According to Roesli (2000) of all breastfeeding mothers' support, husband's support is the most meaningful support for mothers. Mothers tend to want to breastfeed and feel confident if they have the support of their husbands. In addition, the husband will also determine the smoothness of the milk let down reflex reflex which is strongly influenced by the mother's emotions or feelings. Mothers who received husband support tended to exclusively breastfeed twice as much as mothers who lacked husband support (Abdullah and Ayubi, 2013). Support from coworkers in this study is in the form of physical support such as replacing work assignments or psychological support such as encouraging. Rojjannnasrirat in Novayelinda (2012) said that the positive attitude of coworkers towards exclusive breastfeeding is one of the supporting factors for the success of exclusive breastfeeding.

The enabling factor in this study is the provision of special lactation rooms and their supporting facilities. This study shows that some workplaces already provide lactation rooms with very complete facilities. A comfortable lactation room and complete facilities will make it easier for working mothers to pump breast milk while in the office. This is in accordance with the opinion of Rachmawati (2016) that the availability of a place such as a lactation corner in the environment, especially the place of work affects the success of mothers giving exclusive breastfeeding. The more available the facilities, the more chance the mother gives exclusive breastfeeding (Abdullah and Ayubi, 2013). In addition, according to Chen et al (2019) mothers who encounter problems in their work environment will choose to stop breastfeeding or reduce the frequency of breastfeeding for their babies. However there are also workplaces that provide lactation rooms with facilities that are not up to standard and do not even have special ASI spaces.

In accordance with Law No. 36 of 2009 concerning Health, workplaces should provide support for exclusive breast feeding in the form of providing time and special facilities for breastfeeding. The procedure for the Provision of Special Facilities for Breastfeeding is regulated in the Minister of Health Regulation of the Repu- 
blic of Indonesia No.15 of 2013. ASI Room is held in a permanent building, can be a separate room or is part of a part of the health service in the workplace.

Furthermore, according to article 10, the ASI room must meet the following health requirements: a minimum size of $3 \times 4 \mathrm{~m}^{2}$ and/ or adapted to the number of female workers who are breastfeeding, there are doors that can be locked and can be opened or closed easily, cement or ceramic floors or carpets, there is adequate ventilation, pollution-free from outside air (work environment) is not good, the environment is quiet, adequate lighting, humidity ranges between $30-50 \%$, a maximum of $60 \%$, and there is a place to wash hands before and after breastfeeding or blushing ASI and to wash equipment with running water. But apparently the provision of facilities like this has not been fully implemented in all institutions

Based on the results of the above research, some suggestions can be taken, namely the leadership of the workplace must fulfill the rights of women workers to breastfeed exclusively by giving them time to pump breast milk and provide special lactation space in accordance with the eligibility standards set by government regulations. In addition, the leadership's commitment is required to conduct regular monitoring and evaluation of the provision of lactation space so that the lactation space can be used comfortably as it should.

The limitation of this study is that it only involves informants with formal employment status. Further research should also include informants with informal employment status to see the extent of the implementation of government policies carried out in various types of workplaces.

Working mothers in the Greater Jakarta area successfully completed exclusive breastfeeding with various obstacles.
The success of exclusive breastfeeding among working mothers in the Greater Jakarta area must consider the mother's knowledge, mother's perceptions and number of children as predisposing factors; husband's support and colleague support as a reinforcing factor; and supporting facilities in the workplace as an enabling factor.

\section{REFERENCES}

Abdullah GI, Ayubi D (2013). Determinan pemberian air susu ibu eksklusif pada ibu bekerja (Determinants of exclusive breastfeeding for working mothers). Jurnal kesehatan masyarakat Indonesia 7 (7): 298-301. Retrieved from http://journal.fkm.ui.ac.id/kesmas/article/view/27

Badan Kependudukan dan Keluarga Berencana Nasional, Badan Pusat Statistik, Kementerian Kesehatan (2013). Survei demografi dan kesehatan Indonesia 2012 (2012 Indonesia demographic and health survey). Retrieved from http://kesga.kemkes.go.id/images/pedoman /SDKI\%202012-Indonesia.pdf

Badan Kependudukan dan Keluarga Berencana Nasional, Badan Pusat Statistik, Kementerian Kesehatan (2018). Survei demografi dan kesehatan Indonesia 2017 (Indonesia demographic and health survey 2017). Retrieved from http://sdki.bkkbn.go.id/files/buku/2017IDHS. pdf

Badan Pusat Statistik (2018). Presentase tenaga kerja formal menurut jenis kelamin 2015-2018 (Percentage of formal workforce by gender 20152018). Retrieved from https://bps.go.id

Badan Pusat Statistik (Central Bureau of Statistics) (2018). Berita resmi statistik keadaan ketenagakerjaan In- 
donesia Februari 2018 (Official news statistics on the state of Indonesia's employment in February 2018). Retrieved from https://www.turc.or.id

Balogun OO, Dagvadorj A, Anigo KM, Ota E, Sasaki S (2015). Factors influencing breastfeeding exclusivity during the first 6 months of life in developing countries: A quantitative and qualitative systematic review. Matern Child Nutr, 11 (14): 433451. doi: 10.1111/mcn.12180

Chen J, Xin T, Gaoshan J, Li Q, Zou K, Tan $\mathrm{S}$, Cheng $\mathrm{Y}$ et al (2019). The association between work related fac tors and breastfeeding practices among Chinese working mothers: A mixed-method approach. Int Breastfeed J, 14 (28). Retrieved from https://internationalbreastfeedingjournal.biomedcentral.com/articles/10.1186/s13006-019-0223-z

Departemen Kesehatan Republik Indonesia (2010). Gizi seimbang menuju hidup sehat bagi balita (Balanced nutrition towards a healthy life for toddlers). Jakarta: Direktorat jenderal bina kesehatan masyarakat direktorat gizi masyarakat

Ermalena (2017). Indikator kesehatan SDGs di Indonesia (SDGs health indicators in Indonesia). The 4 th ICTOH 2017. Retrieved from https://www.ictoh-tcscindonesia.com

Ministry of Health RI (2013). Hasil riskesdas 2013 (2013 Riskesdas results). Jakarta: Badan penelitian dan pengembangan kesehatan. Retrieved from http://www.depkes.go.id/resources/download/general/Hasil\%20Riskesdas\%202013.pdf

Ministry of Health RI (2018). Hasil utama riskesdas 2018 (The main results of riskesdas 2018). Jakarta: Badan penelitian dan pengembangan kesehatan. Retrieved from https://kemkes.go.id/resources/download/info-terkini/hasil-riskesdas2018.pdf

Ministry of Health RI (2017). Profil kesehatan Indonesia 2017 (Indonesia Health Profile 2017). Jakarta: Pusat Data dan Informasi Kementerian Kesehatan Indonesia. Retrieved from http://www.depkes.go.id/resources/download/pusdatin/profil-kesehatan-indonesia/Profil-Kesehatan-Indonesia-tahun2017.pdf

Ministry of Health RI (2018). Profil kesehatan Indonesia 2018 (Indonesian health profile 2018). Jakarta: Pusat Data dan Informasi Kementerian Kesehatan Indonesia. Retrieved from https://www.depkes.go.id/resources/download/pusdatin/profil -kesehatan-indonesia/Data-danInformasi_Profil-KesehatanIndonesia-2018.pdf

Kurniawan B (2013). Determinan keberhasilan pemberian air susu eksklusif (Determinants of success in exclusive breastfeeding). Jurnal Kedokteran Brawijaya 27 (4). Retrieved from http://www.jkb.ub.ac.id/index.php/jkb/article/viewFile/365/ 346

Pemerintah Indonesia (2009). Undang undang no. 36 tahun 2009 tentang kesehatan. Jakarta: Sekretariat Negara

Pemerintah Indonesia (2013). Peraturan menteri kesehatan republik Indonesia nomor 15 tahun 2013 tentang tata cara penyediaan fasilitas khusus menyusui dan atau memerah air susu ibu (Regulation of the Minister of Health of the Republic 
of Indonesia number 15 of 2013 concerning procedures for providing special facilities for breastfeeding and / or milking breast milk). Jakarta: Sekretariat Negara

Notoatmodjo S (2007). Pendidikan kesehatan dan ilmu perilaku kesehatan (Health education and health behavioral science), Jakarta: Rineka Cipta

Novayelinda R (2012). Telaah literatur: pemberian ASI dan ibu bekerja (Literature review: breastfeeding and working mothers). Jurnal Ners Indonesia 2(2): 177-181

Purwaningsih A, Hasanah O, Utomo W (2015). Hubungan dukungan keluarga terhadap manajemen laktasi pada ibu bekerja (Relationship of family support to lactation management in work ing mothers). Ners jurnal keperawatan 9(2): 174-187. Retrieved from http://ners.fkep.unand.ac.id/index.php/ners/article/download/69/64

Rachmawati D (2008). Studi kualitatif mengenai persepsi ibu baduta dan ibu hamil terhadap ASI eksklusif dan makanan pendamping ASI (MPASI) di wilayah kerja puskesmas depok jaya kelurahan depok jaya
(Qualitative study on the perception of baduta and pregnant women towards exclusive breastfeeding and complementary feeding (MP-ASI) in the working area of the depok jaya health center). Depok: FKM UI

Roesli U (2009). Mengenai ASI eksklusif (Regarding exclusive breastfeeding). Jakarta: Trubus Agriwidya

SDGs Indonesia (2017). Apa itu SDGs? Retrieved from https://www.sdg203oindonesia.org

Soetjiningsih (1997). ASI petunjuk untuk tenaga kesehatan. Jakarta: EGC

Thet MM, Khaing EE, Diamond-Smith N, Sudhinaraset M, Oo S, Aung T (2016). Barriers to exclusive breast feeding in Ayeyarwaddy region in Myanmar: Qualitative findings from mothers, grandmothers and husbands. Journal appetite 96: 6269. doi: 10.1016/j.appet.2015.08.044.

World Health Organization (2008). WHO country cooperation strategy 20072011: Indonesia. New Delhi: World Health Organization 